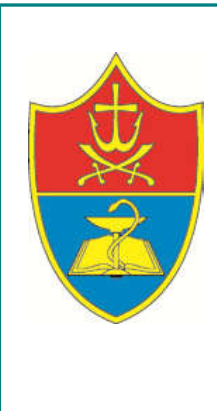

\title{
REPORTS OF MORPHOLOGY
}

\author{
Official Journal of the Scientific Society of Anatomists, \\ Histologists, Embryologists and Topographic Anatomists \\ of Ukraine
}

journal homepage: https://morphology-journal.com

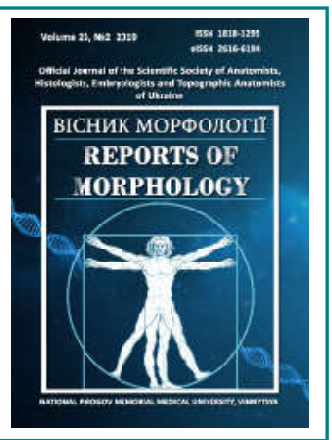

\section{Characteristics of the uterine tubes in the fetal period: topographic and morphometric parallels}

Proniaiev D.V., Bulyk R.Ye

Higher State Educational Establishment of Ukraine "Bukovinian State Medical University", Chernivtsi, Ukraine

\section{ARTICLEINFO}

Received: 25 February, 2019

Accepted: 26 March, 2019

UDC: $611.651 .013 .018-022.5-053.15$

\section{CORRESPONDING AUTHOR}

e-mail: proniaiev@bsmu.edu.ua Proniaiev D.V.
Topicality of the study is stipulated by the importance of objective data for medicine concerning formation of the structure and topographic-anatomical interrelations of the uterine tubes with adjacent organs and structures during the prenatal period of human ontogenesis. Objective: to find and compare tendencies of changes of the uterine tube morphologic parameters in the two groups of fetuses remote in time, and determine age peculiarities of their topography during perinatal period of development. The experimental material (specimens of fetuses) was divided into two groups: I group - 35 specimens of fetuses deceased during 2017-2019; II group - 105 specimens of fetuses taken from the Museum of the Departments of Anatomy, Clinical Anatomy and Operative Surgery at Higher State Educational Establishment of Ukraine "Bukovinian State Medical University", collected during 1970-1990. Every group was subdivided into 7 subgroups according to 10 months of the fetal period of development (from the 4th to the 10th months). The results obtained were statistically processed in the licensed statistical package "Statistica 6.0" using nonparametric methods to evaluate the results. Regular changes in the topography of the right and left uterine tubes, changes in their shape and histological structure are observed. Both uterine tubes were found to occupy an ascending position in thirty cases out of sixty examined specimens of early fetuses (4-6 months of age). In twenty cases one uterine tube was found to be in an ascending position, and in ten cases both uterine tubes were placed practically horizontally. The study of uterine tube morphogenesis in 7-month fetuses found that the structure and topography of the uterine tubes in different age periods differ. In two 7-month fetuses the uterine tubes were found to be in an ascending position, in eight cases one uterine tube (the left one - in six cases out of eight) was in a horizontal position, and in ten cases two uterine tubes were directed practically horizontally. During the 8th month of the antenatal development one uterine tube was found to be in an ascending position out of eight cases; in ten cases both uterine tubes were in the position close to a horizontal one; and in two cases the left uterine tube was in a descending position. In 9-month fetuses both uterine tubes were found to be in a horizontal position in twelve cases, in eight cases one of the uterine tubes was in the position close to a descending one. In fourteen fetuses 10 months of development one uterine tube was in a descending position, and only in six cases both uterine tubes were located horizontally. The length of the uterine tubes of 4-7month fetuses deceased during 2017-2019 was not found to differ reliably. Similar regularity was found in the group of fetuses aged from 9 to 10 months. The length of the uterine tubes of the archival specimens increases reliably every two months. In this group of fetuses the parameters of the uterine tube length aged from 9 to 10 months were found to differ reliably contrary to the length of the uterine tubes in the group of modern specimens of a similar age. Comparison of dynamics in changes of the uterine tube length in the two groups of fetuses remote in time showed that within the frame of one group differences in the morphometric parameters between the right and left uterine tubes are not considerable. Therefore, the study of peculiarities in the structure of the uterine tubes at every stage of the perinatal period found certain peculiarities and regularities of their development. Keywords: uterine tubes, fetus, anatomy, human. 


\section{Introduction}

The importance of studies dealing with spatial-temporal dynamics of transformations of the human organ systems during antenatal period of development is difficult to be overestimated for modern morphological science. A number of scientific works published in modern scientific periodical editions deal with investigation of these processes. The priority and importance of investigations of different organs and/or systems is not possible to determine. Undoubtedly, the study of embryotopography and perinatal morphology of the female reproductive system will contribute greatly in understanding of interrelations and interaction on shapegenerating processes and spatial-temporal organization of anatomical structures, detection of time and morphological preconditions of a possible development of variants in their structure and congenital defects [4]. Though even now literature contains disputable, fragmentary and nonsystematize information concerning age morphological peculiarities of the organ systems of fetuses on the whole and uterine tubes in particular. Certain data [2] determine that close shape-generating interrelations are established between the mesenchymal membrane of the paramesonephral ducts and caudal ligament of mesonephros (Wolffian body/inguinal fold) on the eighth week of development. Some other data determined [3] that the mucous membrane of the uterine tubes during early reproductive age is covered with simple columnar epithelium with a small amount of ciliated and secretory cells available. Single lymphocytes are found in the submucous layer. The serous layer is presented by the mesothelium. At the same time, the muscular layer of the uterine tube wall is found [4] to consist of the external layer (spiral), intermediate layer (circular) and internal one (longitudinal). Moreover, certain differences are found in the scientific literature in definition of terms denoting the origin of the embryo and formation of the paramesonephral ducts, the terms and mechanisms of occurrence of congenital defects of the uterine tubes; different data are contained concerning development of derivatives of the paramesonephral ducts. Little attention is paid to the investigation of the shape, length and diameter of the uterine tubes, histotopography of their walls in the dynamics of the fetal period of ontogenesis. Peculiarities of the structure and structural transformation of the uterine tubes remain a topical issue of morphologists and clinicians [5, 25].

A thorough examination of the perinatal processes of morphogenesis will help to isolate trigger components promoting development of congenital pathology. Defects of the urogenital system are third by their occurrence, including $5,4 \%$ of developmental defects of the uterine tubes.

Determination of accurate and complete information concerning regularities of topographic-anatomical interrelations of the uterine tubes between themselves and adjacent structures during the antenatal period of human ontogenesis, specification of time and morphological preconditions of possible occurrence of their variants of structure and congenital defects is one of the important areas of anatomical science [27].

An active introduction of ante- and perinatal prevention of congenital defects of the internal organs requires modern approaches and methods of investigation of the antenatal period of human ontogenesis. Antenatal diagnostics, therapy, surgical correction and prevention of fetal pathology are the most considerable components of reproductive strategy and perinatology. At the present stage of development of perinatal medicine the main principle should be realized - attitude to the fetus as a patient [26].

A wide introduction of computed tomography, magneticresonance imaging, ultrasound diagnostics into clinical practical work promotes timely detection and prediction of development of perinatal pathology. Considering present requirements, the relations between morphology and clinical studies should be advanced.

Fragmentary and non-systematized character of the scientific studies concerning typical and variant anatomy of the uterine tubes promotes topicality of the study and requirement of its solution. Therefore, topicality of the study is caused by a medical importance of objective data concerning the formation of structure and topographicanatomical interrelations of the uterine tubes with adjacent organs and structures during the prenatal period of human ontogenesis [21-24].

Objective: to find and compare tendencies of changes of the uterine tube morphologic parameters in the two groups of fetuses remote in time, and determine age peculiarities of their topography during perinatal period of development.

\section{Materials and methods}

The scientific study was conducted at the Department of Anatomy, Clinical Anatomy and Operative Surgery, M.G. Turkevych Department of Human Anatomy, at Higher State Educational Establishment of Ukraine "Bukovinian State Medical University" (BSMU), and it is a fragment of their planned scientific-research work "Peculiarities of Morphogenesis and Topography of the Systems and Organs during Pre- and Postnatal Periods of Human Ontogenesis" (state registration № 0115U002769). The materials of the scientific research have been considered by the BSMU Biomedical Ethics Board. The Board approved that the study was performed according to the European Convention for the Protection of Vertebrate Animals Used for Experimental and other Scientific Purposes (18.03.1986), "Ethical Principles for Conducting Research with Human Participants", approved by Helsinki Declaration (1964-2013), ICH GCP (1996), EU Directives № 609 (24.11.1986), the Orders of the Ministry of Health of Ukraine № 690 (23.09.2009), № 944 (14.12.2009), № 616 (03.08.2012). The experimental material (specimens of fetuses) was divided into two groups: I group - 35 specimens of fetuses deceased during 2017-2019; II group - 105 specimens of fetuses taken from the Museum of the Departments of Anatomy, Clinical Anatomy and Operative 
Table 1. Correspondence of fetal length to the term of the fetal development.

\begin{tabular}{|c|c|c|c|c|c|c|c|}
\hline \multicolumn{8}{|c|}{ Modern specimens } \\
\hline Months & 4 & 5 & 6 & 7 & 8 & 9 & 10 \\
\hline \multirow{21}{*}{$\begin{array}{c}\text { Parietal- } \\
\text { calcaneal } \\
\text { length } \\
(\mathrm{mm})\end{array}$} & 165.0 & 210.0 & 260.0 & 310.0 & 355.0 & 405.0 & 455.0 \\
\hline & 170.0 & 220.0 & 260.0 & 310.0 & 360.0 & 420.0 & 455.0 \\
\hline & 170.0 & 220.0 & 270.0 & 325.0 & 360.0 & 430.0 & 460.0 \\
\hline & 180.0 & 230.0 & 280.0 & 340.0 & 370.0 & 430.0 & 465.0 \\
\hline & 180.0 & 240.0 & 300.0 & 340.0 & 380.0 & 445.0 & 470.0 \\
\hline & \multicolumn{7}{|c|}{ Archive specimens } \\
\hline & 170.0 & 210.0 & 260.0 & 310.0 & 355.0 & 410.0 & 455.0 \\
\hline & 170.0 & 210.0 & 260.0 & 310.0 & 355.0 & 410.0 & 455.0 \\
\hline & 170.0 & 210.0 & 260.0 & 310.0 & 355.0 & 410.0 & 455.0 \\
\hline & 170.0 & 220.0 & 265.0 & 320.0 & 360.0 & 420.0 & 460.0 \\
\hline & 170.0 & 220.0 & 265.0 & 320.0 & 360.0 & 420.0 & 460.0 \\
\hline & 170.0 & 220.0 & 270.0 & 320.0 & 360.0 & 425.0 & 460.0 \\
\hline & 170.0 & 225.0 & 270.0 & 330.0 & 360.0 & 430.0 & 460.0 \\
\hline & 170.0 & 230.0 & 275.0 & 335.0 & 365.0 & 430.0 & 465.0 \\
\hline & 180.0 & 230.0 & 275.0 & 340.0 & 365.0 & 430.0 & 465.0 \\
\hline & 180.0 & 235.0 & 290.0 & 340.0 & 370.0 & 440.0 & 465.0 \\
\hline & 180.0 & 240.0 & 290.0 & 340.0 & 370.0 & 440.0 & 465.0 \\
\hline & 180.0 & 240.0 & 300.0 & 340.0 & 370.0 & 440.0 & 470.0 \\
\hline & 180.0 & 245.0 & 300.0 & 345.0 & 380.0 & 445.0 & 470.0 \\
\hline & 180.0 & 250.0 & 300.0 & 345.0 & 380.0 & 445.0 & 470.0 \\
\hline & 185.0 & 250.0 & 300.0 & 350.0 & 380.0 & 445.0 & 470.0 \\
\hline
\end{tabular}

Surgery at Higher State Educational Establishment of Ukraine "Bukovinian State Medical University", collected during 1970-1990. Every group was subdivided into 7 subgroups according to 10 months of the fetal period of development (from the 4th to the 10th months) [1].

The age of fetuses and neonates was determined immediately after obtaining them before preservation by means of measuring the parietal-coccygeal length and parietal-calcaneal length according to A.A. Zavarzin, A.G. Knorre, B.M. Petten tables; recommendations by B.P. Khvatov and Yu.N. Shapovalov, A.I. Brusylovsky and G.G. Avtandilov. Correspondence of fetal length to the term of the fetal development is presented in Table 1. The choice of the preserving solution was caused by the fact that it is this neutral formaldehyde solution according to V.I. Proniayev et al. [20] that least changes the colour of the specimen. The specimens of fetuses were first measured, preserved in 5$7 \%$ formaldehyde solution during 2-3 weeks, and after that kept in $3-5 \%$ formaldehyde solution. The specimens of fetuses from the first group were examined directly in the prosectorium of Chernivtsi Regional Municipal Medical Institution "Pathologic-Anatomical Bureau" during planned dissections.

The results obtained were statistically processed in the licensed statistical package "Statistica 6.0" using nonparametric methods to evaluate the results. The character of distribution for every variation series obtained, mean values for every sign examined, standard quadratic deviation, and percentile scale of parameters were evaluated. Difference reliability of parameters between independent quantitative values was determined by means of Mann-Whitney $U$ criterion $[8,18,23]$.

\section{Results}

While examining peculiarities of the uterine tube structure at every stage of the perinatal period we have found certain peculiarities and regularities of their development. Particularly, regular topographic changes of the right and left uterine tubes, changes of their shape and histological structure were observed. Peculiarities of the uterine tube topography found by us should be characterized by a certain compliance with the ovarian topography, since regular interrelations in the development of these organs are found in the fetal period of human ontogenesis. Numerous studies dealing with investigation of the uterine tube topography of fetuses conducted by scientists $[26,27]$ and published on the pages of periodical scientific editions are indicative of certain unconformity of results. Specifically it is indicated [7, 25] that at the beginning of the fetal period the uterine tubes passing parallel to the dorsal-lateral abdominal wall in a free upper margin of the broad uterine ligament till the end of the fetal period descend synchronously into the pelvic cavity and in all the cases they are located on the level with the uterine fundus. At the same time, their skeletopia changes from the level of the $5^{\text {th }}$ lumbar vertebra at the beginning of the fetal period to the $2^{\text {nd }}$ sacral vertebra in neonates. We can agree with a thesis concerning a skeletopic change of the uterine tube position, but we cannot agree with the thesis about synchronous descending of the right and left uterine tubes to the level of the uterine fundus. We have determined that in 30 out of 60 examined specimens of the early fetuses (4-6 months of age) both uterine tubes were found to be in an ascending position, in 20 cases one uterine tube was in an ascending position and in 10 cases both uterine tubes were located practically horizontally.

We have found successive stages of the uterine tube shapes: conditionally straight, curved, zigzag, and spiral (Fig. 1).

At the beginning of the fetal period (4-5 month fetuses) a zigzag shape of the uterine tubes prevails over the rest of variants of their shape practically twice as much $(50 \%)$. Cases with a spiral shape were found in $30 \%$, and conditionally straight uterine tubes were found in $20 \%$ cases (Fig. 2).

Spiral and zigzag uterine tubes were found in 30 and $70 \%$ of cases respectively in fetuses of 6 months of age.

Examination of the uterine tube morphogenesis of 7month fetuses found that the structure and topography of the uterine tubes at different terms differ. In two fetuses both uterine tubes were in an ascending position, in 8 cases one of the uterine tubes (the left one - in 6 cases out of 8 ) was in 

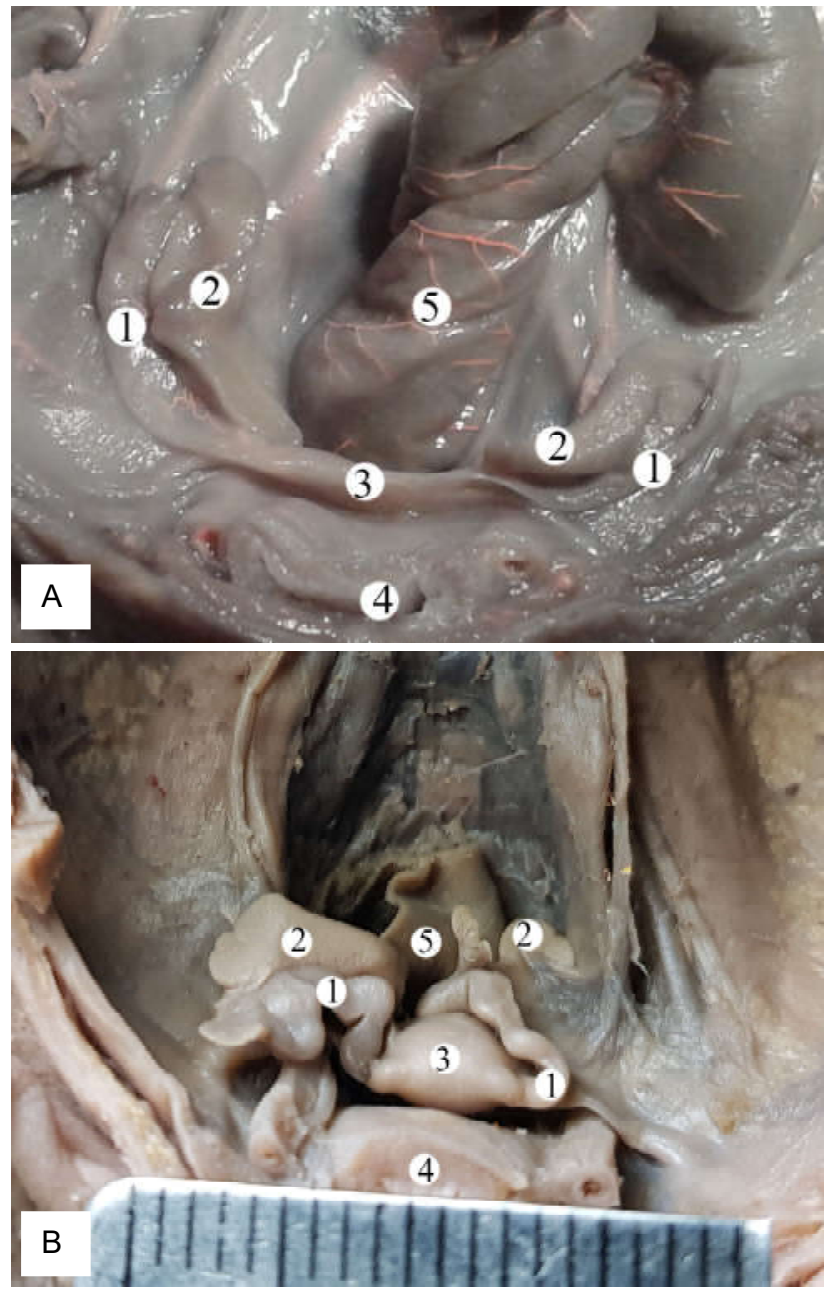

Fig. 1. Internal female reproductive organs of fetuses 210,0 (A) and 300,0 (B) mm of the parietal-calcaneal length. Specimen. 1 uterine tubes; 2 - ovaries; 3 - uterus; 4 - urinary bladder; 5 rectum; A - conditionally straight or curve uterine tubes, B - spiral or zigzag uterine tubes.

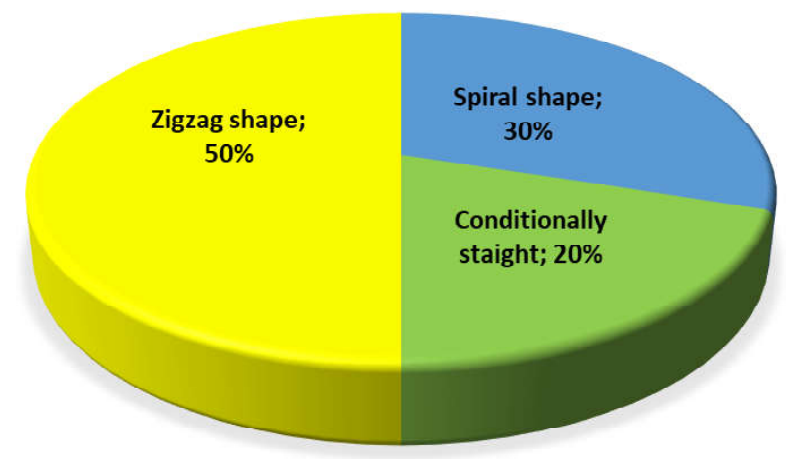

Fig. 2. Variability of shapes of the uterine tubes in 4-5-month fetuses.

a horizontal position, and in 10 cases two uterine tubes were directed practically horizontally.

During the 8th month of the antenatal development one uterine tube was found to be in an ascending position out of eight cases; in ten cases both uterine tubes were in the position close to a horizontal one; and in two cases the left uterine tube was in a descending position (Fig. 3).

In 9-month fetuses both uterine tubes were found to be in a horizontal position in twelve cases, in eight cases one of the uterine tubes was in the position close to a descending one.

In fourteen fetuses 10 months of development one uterine tube was in a descending position, and only in six cases both uterine tubes were located horizontally (Fig. 4).

Analyzing the dynamics of changes of the right uterine tube length in 4-10-month fetuses from the first group (Fig. $5 \mathrm{~A}$ ), it should be noted that its length in 4, 5, 6 and 7 month

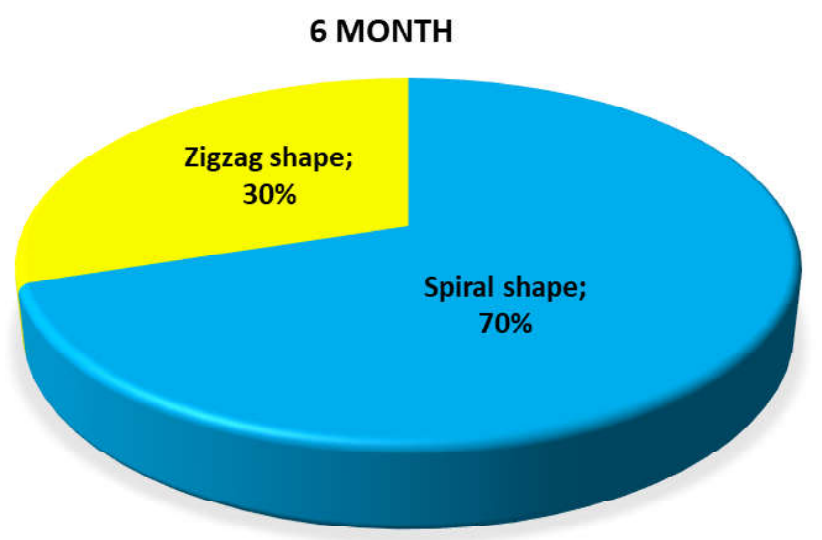

\section{MONTH}

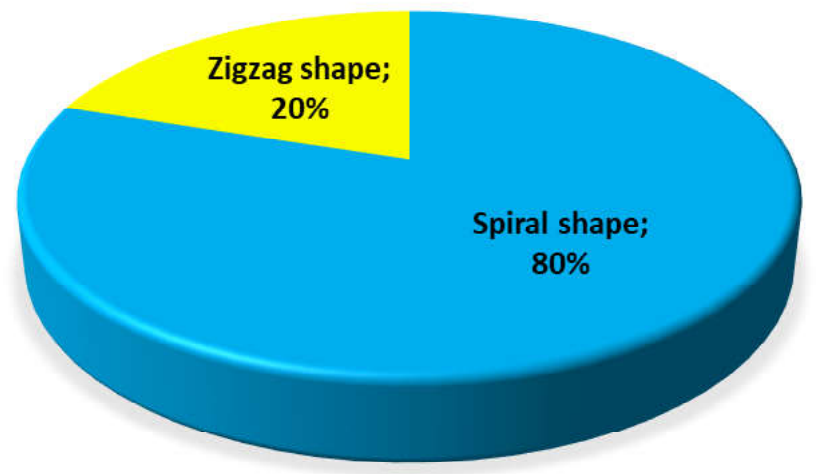

8 MONTH

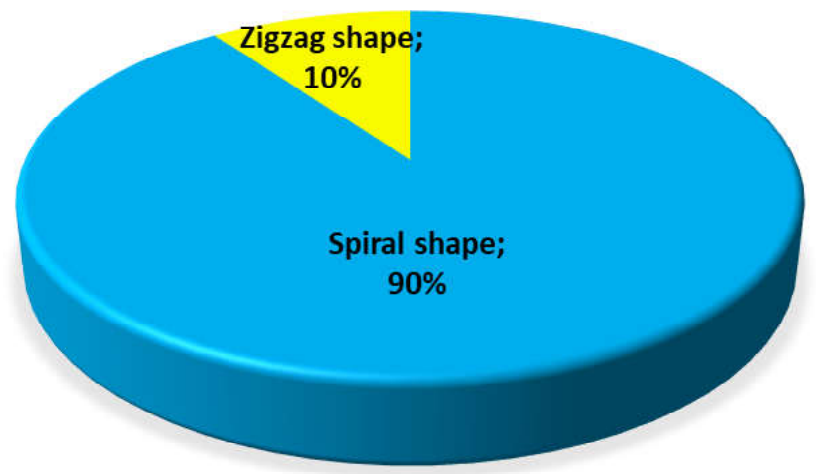

Fig. 3. Variants of uterine tubes in 6-8-month fetuses. 


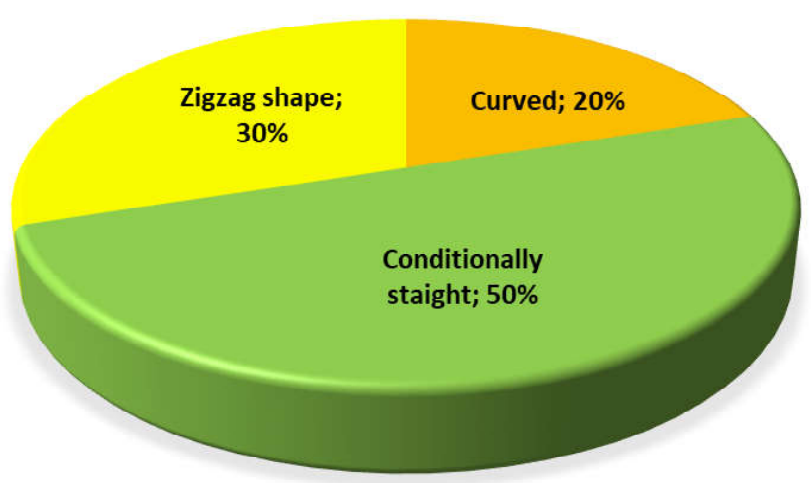

Fig. 4. Variability of the uterine tube shape at the end of the fetal period.
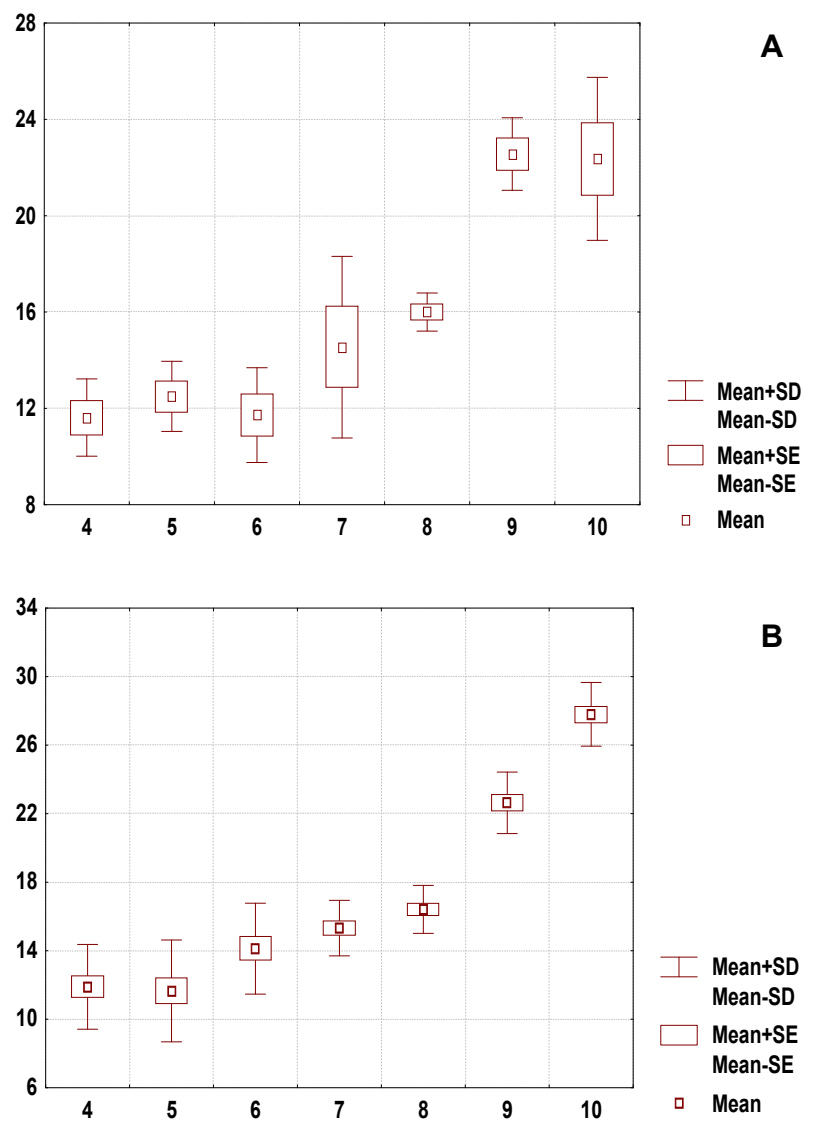

Fig. 5. Length of the right uterine tube of fetuses from different age groups. Here and further: A - first group, the studies of 20172019; B - seconds group, specimens of 1970-1990.

fetuses does not differ reliably similar to that of 7 and 8,9 and 10 month fetuses ( $p>0.05)$. Though, in 4-7 month fetuses its length is reliably shorter than in the rest of terms $(p<0.05-0.01)$.

In fetuses from the second group (Fig. $5 \mathrm{~B}$ ) the length of the right uterine tube in 4-month fetuses does not differ reliably from that of 5 -month fetuses $(p>0.05)$, though it is reliably shorter than that of fetuses of the rest age groups. In 5-month fetuses the length of the right uterine tube is reliably shorter than in 6-10-month fetuses. This parameter of 6 and 7-month fetuses does not differ reliably ( $p>0.05)$. In the rest of cases the length of the right uterine tube in 8month fetuses is reliably shorter than that of 9 and 10month fetuses. In 9-month fetuses this parameter is shorter than that of 10 -month fetuses $(p<0.05-0.01)$.

The dynamics of length of the left uterine tube in fetuses from the first group (Fig. $6 \mathrm{~A}$ ) is similar to that of the right uterine tube. This parameter in 4-7-month fetuses does not differ reliably $(p>0.05)$, though it is reliably shorter than the length of the left uterine tube in $8-10$-month fetuses $(p<0.05$ 0.01 ). There is no reliable difference found in 7 and 8-month fetuses except comparison with the length of the left uterine tube in the first group. There is no reliable difference found between the length of the left uterine tube in the first group of 9 and 10-month fetuses. The length of the left uterine tube in this group of 8-month fetuses is reliably shorter than that of 9 and 10 -month fetuses $(p<0.01)$.

The length of the left uterine tube in the second group has certain considerable peculiarities (Fig. $6 \mathrm{~B}$ ), both in comparison with the length of the right uterine tube in both groups, and in comparison with the same parameter in the first group. That is, there is no reliable difference found between specimens of 4 and 5-month fetuses from the second group in the length of the left uterine tube $(p>0.05)$,
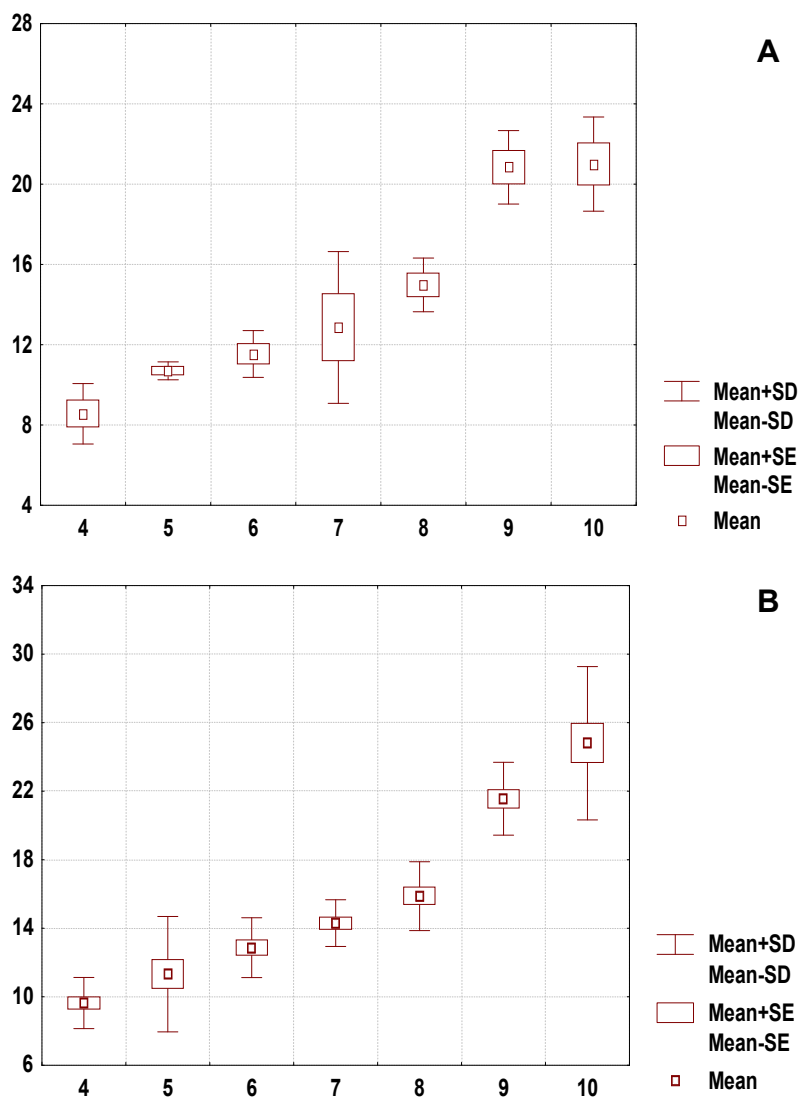

Fig. 6. Length of the left uterine tube of fetuses from different age groups. 
similar to that of 5 and 6-month, 6 and 7-month fetuses. Though, the length of the left uterine tube in 4-month fetuses from the second group is reliably shorter than that of 6-10month fetuses. Similar situation is observed in 5 and $6-$ month fetuses. The length of the left uterine tube in 5-month fetuses is reliably shorter than that of 7-10-month fetuses. The length of the left uterine tube from the second group in 6-month fetuses is reliably shorter than that of 8-10-month fetuses, though it is longer than that in 4-month fetuses $(p<0.05-0.01)$. In this case the length of the left uterine tube in 9 and 10 -month fetuses does not differ reliably $(p<0.001)$. During 7 month of development the length of the left uterine tube in fetuses from the second group is reliably shorter than that in 8-10-month fetuses. Though, it is longer than that in 4 and 5-month fetuses and does not differ from that of 6 -month fetuses $(p>0.05)$. The left uterine tube in 8-month fetuses is reliably shorter than in 9-10-month fetuses and longer than in 4-7-month fetuses.

\section{Discussion}

Summing up the above a conclusion can be drawn concerning nonsynchronous descending of the uterine tubes into the pelvic cavity. Immersion of the uterine tubes into the uterine-rectal depression was often observed in late fetuses, which differs considerably from the results of studies conducted by the majority of authors [16-19].

During perinatal period certain transformations are found in the shape of the uterine tubes. Numerous researchers $[6$, $15,11]$ do not have agreed points of view concerning the shape of uterine tubes and dynamics of its changes. Authors differentiate straight uterine tubes in early fetuses, serpentine uterine tubes - in 6-10-month fetuses. Moreover, they differentiate curved uterine tubes, in the form of "corrugated tube", L-like, C-like, in the form of a hook, etc. Though, the results of our investigations do not allow complete agreement with such definitions, since detection of the uterine tube shape should be based on understanding of regularities of a comprehensive morphological transformations occurring in their walls. The authors have certain reasons to consider that topography and location of the uterine tubes depend on the degree of development and position of the ovaries, that is: the longer ovarian length the more inclined position of the uterine tube is.

The importance of the suspensory ligament of the ovary concerning its topography and topography of the uterine tube is a well-known fact [7-9, 24]. Of course, there are no grounds to refuse it, but we think that the processes of morphogenesis having a leading value during the embryonic period produce less effect on morphological transformations during the perinatal period. Since the 5 th month of the antenatal

\section{References}

[1] About the introduction of Instructions about the recognition of criteria for live births, dead births and the perinatal period. The order of the Ministry of Health of Ukraine № 179 (z0427-06) 29.03.2006. https://zakon.rada.gov.ua/laws/show/z0160-96 [2]Acién, P., \& Acién, M. (2016). Diagnostic imaging and cataloguing development leading morphological transformations occur at the expense of plastic processes both in the wall of the uterine tube and ovarian parenchyma. And it is these processes produce a crucial value on the formation of topography and morphology of the fetal uterine tube. That is, in our studies we indicate that with the beginning of the perinatal period a leading role concerning detection of anatomical characteristics changes between the uterine tube and ovary. During the embryonic and pre-fetal periods the ovaries with their suspensory apparatus determine topography of the uterine tubes [10-11], but during the fetal period ovarian topography depends on the topography of the uterine tubes.

Analysis of the statistical investigation conducted is indicative of certain peculiarities of age dynamics in transformation of morphometric parameters of the uterine tubes during the fetal period. The length of the uterine tubes of 4-7-month fetuses deceased during 2017-2019 was not found to differ reliably. Similar regularity was found in the group of fetuses aged from 9 to 10 months. The length of the uterine tubes of the archival specimens increases reliably every two months $(p>0.05)$. In this group of fetuses the parameters of the uterine tube length aged from 9 to 10 months were found to differ reliably contrary to the length of the uterine tubes in the group of modern specimens of a similar age.

Comparison of dynamics in changes of the uterine tube length in the two groups of fetuses remote in time showed that within the frame of one group differences in the morphometric parameters between the right and left uterine tubes are not considerable. Though, a tendency can be observed concerning a relative enlargement of length of both uterine tubes among the specimens of fetuses from the second group.

\section{Conclusions}

1. In 4-8-month fetuses the uterine tubes descend gradually: from the ascending position near the rectum to the iliac fossa or the uterine-rectal depression.

2. Dynamics of both uterine tubes demonstrates a tendency to a relative enlargement of length of bot uterine tubes among museum (archive) specimens of 10-month fetuses. The length of the uterine tubes of 4-7-month fetuses deceased during 2017-2019 was not found to differ reliably. Similar regularity was found in the group of fetuses aged from 9 to 10 months. The length of the uterine tubes of the archival specimens increases reliably every two months. In this group of fetuses the parameters of the uterine tube length aged from 9 to 10 months were found to differ reliably contrary to the length of the uterine tubes in the group of modern specimens of a similar age.

of female genital malformations. Insights into Imaging, 7(5), 713-726. doi: 10.1007/s13244-016-0515-4

[3] Ando, H., Watanabe, Y., Ogawa, M., Tamura, H., Deguchi, T., Ikeda, K., ... Adachi, S. (2017). Mesonephric adenocarcinoma of the uterine corpus with intracystic growth completely 
confined to the myometrium: a case report and literature review. Diagnostic Pathology, 12(1), 63. doi: 10.1186/s13000017-0655-y

[4] Akhtemiichuk, Yu. T., \& Piatnytska, T. V. (2010). Histotopography of the uterine tubes in human fetuses. Clinical Anatomy and Operative Surgery, 9(4), 50-54.

[5] Akhtemiichuk, Yu. T., Piatnytska, T. V., \& Manchulenko, D. G. (2012). Morphogenesis of the uterine tubes during prenatal period of human ontogenesis. Theses published in the Materials of the 3rd Scientific Symposium "Anatomical-Surgical Aspects of Pediatric Gastroenterology", Chernivtsi. Chernivtsi: BSMU.

[6] Akhtemiichuk, Yu. T., Piatnytska, T. V., \& Marchuk, V. F. (2011). Microstructure of the uterine tubes during the prenatal period of ontogenesis. Theses published in the Materials of the Scientific-Practical Conference: "Morphological Aspects of Microcirculation in the Norm and Pathology". Ternopil: Ukrmedknyha.

[7] Banul, B. Yu., \& Marchuk, F. D. (2013). Development of the uterine tubes at the end of the fetal period of human ontogenesis. Bukovinian Medical Herald, 18(2), 206-208.

[8] Banul, B. Yu., Marchuk, F. D., \& Liutyk, M. D. (2013). Development of the uterine tubes at the end of the pre-fetal and early fetal periods of human ontogenesis. Theses published in the Materials of the $94^{\text {th }}$ Final Scientific Conference of the Professional and Teaching Staff of Bukovinian State Medical University, Chernivtsi. Chernivtsi: BSMU.

[9] Caliskan, S. (2017). Bilateral ureteral duplication of complete left and incomplete right side with lower pole kidney stone. Journal of the College of Physicians and Surgeons, 27(3), 65-66. PMID: 28302252

[10] Chapel, D. B., Joseph, N. M., Krausz, T., \& Lastra, R. R. (2018). An Ovarian Adenocarcinoma With Combined Low-grade Serous and Mesonephric Morphologies Suggests a Müllerian Origin for Some Mesonephric Carcinomas. International Journal of Gynecological Pathology, 37(5), 448-459. doi: 10.1097/ PGP.0000000000000444

[11] Darcy, D. G., Yao-Cohen, M., Olson, T. R., \& Downie, S. A. (2017). Unilateral complete agenesis of mesonephric duct derivatives in an 82-year-old male cadaver: embryology, anatomy and clinical considerations. Urology Case Reports, 15, 20-22. doi: 10.1016/j.eucr.2017.06.003

[12] Davidson, E. R. W., \& Barber, M. D. (2017). Agartner duct cyst masquerading as anterior vaginal prolapse. Obstetrics \& Gynecology, 130(5), 1039-1041. doi: 10.1097/ AOG.0000000000002315

[13] George, C., \& Berge, L. R. (2002). Hypothesis Testing. Statistical Inference. Second Edition. Pacific Grove, CA: Duxbury.

[14] Jin, Z. W., Abe, H., Hinata, N., Li, X. W., Murakami, G., \& Rodriguez-Vázquez, J. F. (2016). Descent of mesonephric duct to the final position of the vas deferens in human embryo and fetus. Anatomy \& Cell Biology, 49(4), 231-240. doi: 10.5115/ acb.2016.49.4.231

[15] Khmara, T. V., \& Voitenko, S. G. (1994). To the issue of development of the human uterine tubes. Theses published in the Materials of the Conference "Scientists of Bukovyna to the Public Health Care", Chernivtsi: [w.p.].
[16] Ludwig, K. S. (1993). The development of the caudal ligaments of the mesonephros and of the gonads: a contribution to the development of the human gubernaculum (Hunteri). Anatomy and Embryology, 88, 571-577. doi: 10.1007/bf00187012

[17] Mirkovic, J., McFarland, M., Garcia, E., Sholl, L. M., Lindeman, N., MacConaill, L., ... \& Howitt, B. E. (2018). Targeted genomic profiling reveals recurrent kras mutations in mesonephric-like adenocarcinomas of the female genital tract. The American Journal of Surgical Pathology, 42(2), 227-233. doi: 10.1097/ PAS.0000000000000958

[18] Moisiuk, D. V., Syniuk, O. S., \& Zayats, V. V. (2006). Peculiarities of the uterine tube structure. Theses published in the Materials of the IV International Scientific-Practical Conference of Students and Young Scientists, Uzhgorod. Uzhgorod: Grazhda.

[19] Piantnytska, T. V. (2010). Formation of the uterine tubes during the pre-fetal period of ontogenesis. Theses published in the Materials of the Scientific-Practical Conference devoted to the 70th anniversary of the Honoured Scientist and Technician of Ukraine, Professor Ya.I. Fedoniuk "Topical Issues of Morphology", Ternopil. Ternopil: Ukrmedknyha.

[20] Pronyayev, V. I., Svistonyuk, I. U., \& Akhtemiychuk, Yu. T. (1995). Changes in the length of embryos depending on their age, type and concentration of fixatives. Thesis in materials of "International Congress on Integrative Anthropology". Ternopil': [w.p].

[21] Puljiz, M., Danolić, D., Kostić, L., Alvir, I., Tomica, D., Mamić, I., \& Balja, M. P. (2016). Mesonephric adenocarcinoma of endocervix with lobular mesonephric hyperplasia: case report. Acta Clinica Croatica, 55(2), 326-330. doi: 10.20471/ acc.2016.55.02.22

[22] Roder, D., Davy, M., Selva-Nayagam, S., Paramasivam, S., Adams, J., Keefe, D., ... Oehler, M. K. (2018). Exploring the added value of hospital-registry data for showing local service outcomes: cancers of the ovary, fallopian tube and peritoneum. BMJ Open, 9(2), e024036. doi: 10.1136/bmjopen-2018-024036

[23] Shelamova, M. A., Insarova, N. I., \& Leshchenko, V. H. (2010). Statistical analysis of medical-biological data using Excel program. Teaching-Methodical Manual. Minsk: BSMU.

[24] Singh, K., Sung, C. J., Lawrence, W. D., \& Quddus, M. R. (2017). Testosterone-induced "virilization" of mesonephric duct remnants and cervical squamous epithelium in femaleto-male transgenders: a report of 3 cases. The International Journal of Gynecological Pathology, 36(4), 328-333. doi: 10.1097/PGP.0000000000000333

[25] Tiwari, C., Shah, H., Desale, J., \& Waghmare, M. (2017). Neonatal gartner duct cyst: two case reports and literature review. Developmental Period Medicine, 21(1), 35-37. PMID: 28551690

[26] Voitenko, S. G. (1996). Topography of the uterine tubes during the fetal period of human ontogenesis. Theses published in the Materials of the Scientific Conference "Topical Issues of Morphogenesis", Chernivtsi. Chernivtsi: [w.p.].

[27] Yeo, M. K., Choi, S. Y., Kim, M., Kim, K. H., \& Suh, K. S. (2016). Malignant mesonephric tumor of the cervix with an initial manifestation as pulmonary metastasis: case report and review of the literature. European journal of gynaecological oncology, 37(2), 270-277. PMID: 27172762

\section{ХАРАКТЕРИСТИКА МАТКОВИХ ТРУБ У ПЛОДОВОМУ ПЕРІОДІ: ТОПОГРАФІЧНІ ТА МОРФОМЕТРИЧНІ ПАРАЛЕЛІ} Проняє Д.В., Булик Р.Є.

Актуальність даного дослідження зумовлена важливістю для медицини об'єктивних даних про становлення будови $і$ топографоанатомічних взаємовідношень маткових труб зі суміжними органами та структурами в пренатальному періоді онтогенезу людини. Мета роботи - встановити та порівняти тендениії змін морфологічних параметрів маткових труб двох віддалених у часі груп плодів та з'ясувати вікові особливості їх топографії у перинатальному періоді розвитку. 
Дослідний матеріал (препарати плодів) було розподілено на дві групи: I група - 35 препаратів плодів, котрі померли впродовж 2017-2019 рр; II група - 105 препаратів плодів із музею кафредри анатомії, клінічної анатомії та оперативної хірургії Вищого державного навчального закладу України "Буковинський державний медичний університет", що були зібрані впродовж 19701990 рр. Кожну із груп було розподілено на 7 підгруп відповідно 10-ти місяцям плодового періоду розвитку (з 4-го по 10-й). Статистичний аналіз отриманих результатів проведений у ліцензійному статистичному пакеті "Statistica 6.0" 3 використанням непараметричних методів оцінки результатів. Встановлені закономірні зміни топографрії правої та лівої маткових труб, зміна їх форми та гістологічної будови. Виявлено, що із 60 досліджених препаратів ранніх плодів (віком 46 місяців) у 30 випадках обидві маткові труби займали висхідне положення, у 20 випадках одна маткова труба займала висхідне положення і в 10 випадках дві маткові труби розташовувались майже горизонтально. При дослідженні морфогенезу маткових труб плодів 7 місяців внутрішньоутробного розвитку виявлено, що будова і топографрія маткових труб у різні вікові періоди має свої відмінності. У двох плодів віком 7 місяців дві маткові труби займали висхідне положення, у 8 випадках одна з маткових труб (ліва - у 6 випадках із 8) займала горизонтальне положення і в 10 випадках дві маткові труби спрямовувалися майже горизонтально. На восьмому місяці внутрішньоутробного розвитку у 8 випадках, одна $з$ маткових труб займала висхідне положення, у 10 випадках обидві маткові труби займали положення, наближене до горизонтального, і в 2 випадках ліва маткова труба займала низхідне положення. У плодів 9 місяців у 12 випадках обидві маткові труби займали горизонтальне положення, а у 8 випадках - одна з маткових труб займала положення, наближене до низхідного. У 14 плодів віком 10 місяців одна маткова труба займала низхідне положення і лише в 6 випадках обидві маткові труби розташовувались горизонтально. Встановлено, що довжина маткових труб плодів віком 4-7 місяців, що померли впродовж 2017-2019 рр., достовірно не відрізнялась. Аналогічну закономірність встановлено для груп плодів віком 9 та 10 місяців. Довжина маткових труб архівних препаратів кожні 2 місяці достовірно збільшується. В даній групі також достовірно відрізняються параметри довжини маткових труб плодів віком 9 та 10 місяців на відміну від довжини маткових труб плодів групи сучасних препаратів аналогічного віку. Порівняння динаміки зміни довжини маткових труб двох розведених у часі груп плодів показало, що в межах однієї групи відмінності в морфометричних параметрах між правою та лівою матковою трубою є незначними. Таким чином, при дослідженні особливостей будови маткових труб на кожному з етапів перинатального періоду виявлені певні особливості та закономірності їх розвитку.

Ключові слова: маткові труби, плід, анатомія, людина.

\section{ХАРАКТЕРИСТИКА МАТОЧНЫХ ТРУБ В ПЛОДОВОМ ПЕРИОДЕ: ТОПОГРАФИЧЕСКИЕ И МОРФОМЕТРИЧЕСКИЕ ПАРАЛЛЕЛИ \\ Проняев Д.В., Булык Р.Е.}

Актуальность данного исследования обусловлена важностью для медицины объективных данных о становлении строения и топографро-анатомическом взаимоотношении маточных труб со смежными органами и структурами в пренатальном периоде онтогенеза человека. Цель работы - определить и сравнить тенденции изменений морфологических параметров маточных труб двух отдаленных во времени групп плодов и выяснить возрастные особенности их топографии в перинатальном периоде развития. Исследуемый материал (препараты плодов) был разделен на две группы: I группа - 35 препаратов плодов, умерших в течение 2017-2019 ге; II группа - 105 препаратов плодов из музея кафедры анатомии, клинической анатомии и оперативной хирургии Высшего государственного учебного заведения "Буковинский государственный медицинский университет", собранные в течение 1970-1990 г2. Каждую из групп распределили на 7 подгрупп соответственно 10-ти месяцам плодного периода развития (с 4-го по 10-й). Статистический анализ полученых результатов выполнен в лицензионном статистическом пакете "Statistica 6.0" с использованием непараметричеких методов оценки результатов. Установлены закономерные изменения топографии правой и левой маточных труб, изменение их формы и гистологического строения. Выявлено, что из 60 исследованных препаратов ранних плодов (в возрасте 4-6 месяцев) в 30 случаях обе маточные трубы занимали восходящее положение, в 20 случаях одна маточная труба занимала восходящее положение и в 10 случаях две маточные трубы располагались почти горизонтально. При исследовании морфогенеза маточных труб плодов 7 месяцев внутриутробного развития, выявлено что строение и топография маточных труб в разные возрастные периоды имеют свои отличия. У двух плодов в возрасте 7 месяцев две маточные трубы занимали восходящее положение, в 8 случаях одна из маточных труб (левая - в 6 случаях из 8) занимала горизонтальное положение и в 10 случаях две маточные трубы направлены почти горизонтально. На 8 месяце внутриутробного развития в 8 случаях, одна из маточных труб занимала восходящее положение, в 10 случаях обе маточные трубы занимали положение, близкое к горизонтальному, и в 2 случаях левая маточная труба занимала нисходящее положение. У плодов 9 месяцев в 12 случаях обе маточные трубы занимали горизонтальное положение, а в 8 случаях - одна из маточных труб занимала положение, близкое к нисходящему. У 14 плодов в возрасте 10 месяцев одна маточная труба занимала нисходящее положение и только в 6 случаях обе маточные трубы размещались горизонтально. Установлено, что длина маточных труб плодов в возрасте 4-7 месяцев, умерших на протяжении 2017-2019 г2., достоверно не отличается. Аналогичную закономерность установлено для групп плодов возрастом 9 и 10 месяцев. Длина маточных труб архивных препаратов каждые 2 месяца достоверно увеличивается. В данной группе также достоверно отличаются параметры длины маточных труб плодов возрастом 9 и 10 месяцев в отличии от длины маточных труб плодов группы современных препаратов соответствующего возраста. Сравнение динамики изменений длины маточных труб в двух разведенных во времени групп плодов показало, что в границах одной группы различия в морфометрических параметрах между правой и левой маточной трубой являются незначительными. Таким образом, при исследовании особенностей строения маточных труб на каждом из этапов перинатального периода выявлены определенные особенности и закономерности их развития.

Ключевые слова: маточные трубы, плод, анатомия, человек. 